\title{
Infestation of Glycaspis brimblecombei Moore on Thirteen Eucalyptus Species and Their Relationship with the Chemical Composition of Essential Oils
}

\begin{abstract}
Alejandro Lucia, Cecilia Naspi, Eduardo Zerba, and Héctor Masuh
Centro de Investigaciones de Plagas e Insecticidas, CITEDEF, CONICET, J. B. de La Salle 4397, Villa Martelli, B1603ALO Buenos Aires, Argentina

Correspondence should be addressed to Héctor Masuh; hmasuh@citedef.gob.ar

Received 3 September 2015; Revised 23 December 2015; Accepted 6 January 2016

Academic Editor: Dmitri Y. Boudko

Copyright $\odot 2016$ Alejandro Lucia et al. This is an open access article distributed under the Creative Commons Attribution License, which permits unrestricted use, distribution, and reproduction in any medium, provided the original work is properly cited.

Glycaspis brimblecombei is a pest insect that affects Eucalyptus genus and was firstly detected in Argentina in 2005. The main objective of this study is to determine the correlation between the level of infestation and chemical composition of essential oils extract. In an experimental plantation of 13 Eucalyptus species, the natural presence of the psyllid in the adaxial and abaxial faces of the leaves was determined and the mean number of individuals per species was calculated. The essential oils were extracted by hydrodistillation and analyzed for their chemical composition by gas chromatography-mass spectrometry. The results showed that 7 out of 13 species of Eucalyptus were not affected by G. brimblecombei: E. dunnii, E. globulus maidenii, E. globulus ssp. globulus, E. viminalis, E. cinerea, E. sideroxylon, and E. gunnii. The most affected Eucalyptus species were E. tereticornis and E. camaldulensis whereas the infestation in E. grandis $\times$ E. tereticornis and E. grandis $\times$ E. camaldulensis was intermediate. E. saligna and E. grandis were the least affected species. The relative concentrations of the compounds 1,8-cineole and $\alpha$-and $\beta$-phellandrene in the essential oils are highly correlated to the rate of infestation with G. brimblecombei.
\end{abstract}

\section{Introduction}

Glycaspis brimblecombei Moore (Hemiptera: Aphalaridae) is a psyllid known as Eucalyptus red gum lerp psyllid. This psyllid has 5 nymphal instars (immatures). Adults (3 mm long) are brown or pale green, easily distinguished by their long genal cones on the head [1-3]. Both adults and immatures cause great damage to foliage, characterized by discoloration in leaves, reduction in photosynthetic area, growth reduction, and dried sprouts [3]. This pest was originally detected in Australia by Moore [4], later in Queensland, New South Wales, Brazil, and Chile $[1,5]$. In February 2005, it was first detected in Argentina (Concordia Department, Entre Ríos Province) on E. camaldulensis Dehnh. [6].

G. brimblecombei is associated exclusively with trees of Eucalyptus genus (Myrtaceae) and its natural environment involves a great number of species. Moore [4] detected this psyllid in E. camaldulensis Dehnh., E. blakelyi Maiden, E. nitens Maiden, E. tereticornis Smith, E. dealbata Cunn. ex Schauer, and E. bridgesiana Baker, among others [4]. These last ones plus other Eucalyptus species were also reported as G. brimblecombei hosts: E. brassiana Blake, E. camphora Baker, and E. mannifera Baker [7]. In California, the psyllid was also detected in E. diversicolor F. Muell., E. globulus Labill., and E. sideroxylon Cunn. [7]. Eucalyptus camaldulensis Dehnh. and E. tereticornis Smith, both known as "red Eucalyptus," were reported as highly susceptible to the psyllid attack; E. grandis Hill (ex Maiden) and E. saligna Smith susceptibility are intermediate $[5,6,8]$.

Many Eucalyptus species contain essential oils; at least twenty of them are commercially exploited for oil production [9]. Essential oils are obtained by hydrodistillation of leaves and are constituted by a mixture of hydrocarbons, terpenes and sesquiterpenes, and oxygenated compounds such as alcohols, esters, ethers, aldehydes, ketones, lactones, and phenols [9]. In Argentina, Eucalyptus has been used for reforestation and as a wood resource since the 1950s [10].

Terpenoids can act as kairomones. Some monoterpenes are responsible for attraction of bark insects such as 
Scolytus ventralis LeConte, Dendroctonus frontalis Zimmermann, Dendroctonus ponderosae Hopkins, and Dendroctonus brevicomis LeConte [11]. Terpenes that are emitted by Pinus sylvestris $\mathrm{L}$. in response to the oviposition of pine sawfly attract Chrysonotomyia ruforum Krausse, an egg parasitoid [12]. Ulmus americana L., when affected by the pathogen Ceratocystis ulmi Buisman, increases the production of an odor, which is different from healthy ones: $\alpha$-cubebene [13]. Some authors demonstrate attractiveness and oviposition preference of Glycaspis brimblecombei in Eucalyptus camaldulensis [14], and the role of cuticular waxes was also studied, related to genetic resistance of Eucalyptus globulus [15]. But none of these authors related these preferences to the chemical composition of their essential oils.

The main objective of this work was to study the differential susceptibility of Eucalyptus species to G. brimblecombei and the relationship with the chemical composition of their essential oils. It is expected that a different chemical profile of the essential oils as well as the quantities of oil production in Eucalyptus (Myrtaceae) influences the infestation rate by G. brimblecombei. Deep knowledge of this interaction could lead us to find chemical compounds useful for monitoring or controlling the psyllid G. brimblecombei.

\section{Materials and Methods}

2.1. Plant Material. An experimental plot consisting of thirteen species of genus Eucalyptus (one block per species consisting of 9 individuals each) was constructed in July 2004. The field was located at $34^{\circ} 33^{\prime} 42^{\prime \prime} \mathrm{S}, 58^{\circ} 30^{\prime} 39^{\prime \prime} \mathrm{W}$, CIPEIN (Pest and Pesticides Research Center), Villa Martelli, Buenos Aires, Argentina. The experimental plot was built by twomonth-old and $15 \mathrm{~cm}$ high seedlings.

The following Eucalyptus species were acquired in Paul Forestal Forest Nursery (INASE N ${ }^{\circ} \mathrm{J} / 5188$, San Isidro, Buenos Aires, Argentina): E. saligna, E. dunnii Maiden, E. globulus ssp. maidenii F. v. Muell., E. globulus ssp. globulus Labill., E. viminalis Labill., E. tereticornis, E. camaldulensis, and two clonal hybrids: E. grandis $\times E$. tereticornis and E. grandis $\times E$. camaldulensis. Meanwhile, E. cinerea F. v. Muell. (ex Benth.), E. sideroxylon Cunn., and E. gunnii Hook were purchased from Ferrari Hnos Forest Nursery ( ${ }^{\circ}$ INASE JL/2122, La Plata, Buenos Aires, Argentina).

2.2. Susceptibility of Eucalyptus spp. to Glycaspis brimblecombei. Between January and February 2006, when Eucalyptus plants were 18 months old, the natural presence of psyllids was observed. In order to determinate the infestation of G. brimblecombei (i.e., lerp abundance), a single and direct observation of plant individuals was performed. All plants were counted for their lerp abundance in a period of 1-2 days. The lerps were $4 \mathrm{~mm}$ in diameter and whitish in appearance. The number of lerps found on both surfaces (adaxial and abaxial) of every leaf in the nine plants for each Eucalyptus species was recorded. The trees used for this study were similar in size and foliage abundance.

2.3. Extraction of Essential Oils from Eucalyptus. The essential oils of the thirteen Eucalyptus species were obtained by the hydrodistillation method in a modified Clevenger-type apparatus. The extraction procedure was performed during 70 minutes, time at which the yield remained constant [16]. In March 2006 (30 days after determination of lerp abundance), fresh leaves from each Eucalyptus individual were collected ( $800 \mathrm{~g}$ each). Five independent extractions, consisting of a mixture of nine individuals, were performed for each Eucalyptus species. After extraction, the essential oil was separated from water and dried over anhydrous sodium sulfate. The essential oils were maintained at $-4^{\circ} \mathrm{C}$ until their use.

2.4. Chemical Analyses of Essential Oils from Eucalyptus. The chemical composition of Eucalyptus essential oils was determined by gas chromatography coupled to mass spectrometry using a GCMS-QM 5050A instrument (Shimadzu, Kyoto, Japan) and it is reported in previous publications of our research group $[16,17]$. Gas chromatography conditions were as follows: injection of $0.4 \mu \mathrm{L}$ of a hexane solution of Eucalyptus essential oil ( $1 \mathrm{mg} / \mathrm{mL})$; capillary column HP-1 (crosslinked methyl silicone gum $)(50 \mathrm{~m} \times 0.32 \mathrm{~mm} \times 0.52 \mu \mathrm{m})$; and helium as carrier gas $(1.3 \mathrm{~mL} / \mathrm{min})$. The analytical conditions were as follows: injector and interface temperatures of 250 and $280^{\circ} \mathrm{C}$, respectively, split ratio of $13: 1$, initial isothermic temperature of $50^{\circ} \mathrm{C}$ during $10 \mathrm{~min}$, programed temperature of 50 to $68^{\circ} \mathrm{C}\left(1^{\circ} \mathrm{C} / \mathrm{min}\right)$, programed temperature of 68 to $75^{\circ} \mathrm{C}\left(0.5^{\circ} \mathrm{C} / \mathrm{min}\right)$, programed temperature of 75 to $250^{\circ} \mathrm{C}$ $\left(20^{\circ} \mathrm{C} / \mathrm{min}\right)$, final isothermic temperature of $280^{\circ} \mathrm{C}$ during $10 \mathrm{~min}$, and electron impact $70 \mathrm{eV}$. Compounds identified in the samples were confirmed by comparing their GC retention times with standards through a comparison of the mass spectra with available NIST or Wiley mass spectral library resident in the system. Quantification of essential oil components (expressed in relative percentage on total area of chromatogram) was carried out by peak area normalization measurements. Based on these results, it can be observed that the main component in E. cinerea, E. globulus ssp. maidenii, E. globulus ssp. globulus, E. sideroxylon, and E. viminalis is 1,8-cineole (Table 1). The hybrids E. grandis $\times$ E. tereticornis and E. grandis $\times$ E. camaldulensis are characterized by 1,8 cineole and $\alpha$-pinene. The essential oils from $E$. tereticornis and E. camaldulensis are composed of 1,8-cineole, $\alpha$ - and $\beta$ phellandrene, and $p$-cymene [16]. The chemical composition of the essential oils obtained from E. dunnii and E. gunnii is a complex mixture; the main components are 1,8-cineole, $\gamma$ terpinene, $p$-cymene, and spathulenol [16]. Finally, E. grandis is characterized by high concentrations of $\alpha$-pinene [17].

2.5. Statistical Analysis. The number of lerps for each species was expressed by means of nine independent individuals replicates ( \pm standard deviation). The data were tested for their normality distribution by Kolmogorov and Smirnov test (GraphPad Instat ${ }^{\circledR}$ Vers. 3.01, Copyright 1992-1998, San Diego, California, USA). The homoscedasticity of data was analyzed by Bartlett method (GraphPad Instat Vers. 3.01). These values were submitted to variance analysis (ANOVA) and then compared by Tukey's HSD (honest significant difference) test, using Statgraphics Plus Software Version 4.0 for Windows (Statpoint Technologies, Inc., 1994-1999, Herndon, 
TABLE 1: Lerps abundance of Glycaspis brimblecombei on Eucalyptus species. Mean of number of lerps per individual \pm SE. Different letters are significantly different (Tukey's HSD mean multiple comparison test, $P<0.05)$. Uninfested species are not showed.

\begin{tabular}{lc}
\hline Eucalyptus species & $\begin{array}{c}\text { Number of lerps/individual } \\
\pm \text { standard deviation }\end{array}$ \\
\hline E. grandis & $3 \pm 1.2^{\mathrm{c}}$ \\
E. saligna & $4.6 \pm 2.4^{\mathrm{c}}$ \\
E. grandis $\times$ E. camaldulensis & $21.4 \pm 5.5^{\mathrm{b}}$ \\
E. grandis $\times$ E. tereticornis & $25 \pm 10.2^{\mathrm{b}}$ \\
E. camaldulensis & $356 \pm 63.5^{\mathrm{a}}$ \\
E. tereticornis & $446 \pm 95.3^{\mathrm{a}}$ \\
E. cinerea & 0 \\
E. globulus ssp. maidenii & 0 \\
E. globulus ssp. globulus & 0 \\
E. sideroxylon & 0 \\
E. viminalis & 0 \\
E. gunnii & 0 \\
E. dunnii & 0 \\
\hline
\end{tabular}

VA, USA). A $P$ value $<0.05$ was considered statistically significant. The regression analysis was performed using the same software. The quality of each regression model was evaluated using the coefficient of determination $\left(R^{2}\right), P$ value, and $F$ ratio value $(F)$.

\section{Results}

3.1. Susceptibility of Eucalyptus spp. to Infestation of Glycaspis brimblecombei. The infestation of G. brimblecombei on different Eucalyptus species is showed and presented (Table 1). From the thirteen species of Eucalyptus that we studied, only six were infested by the psyllid (Figure 1): E. tereticornis, E. camaldulensis, E. saligna, E. grandis, and the hybrids E. grandis $\times E$. tereticornis and E. grandis $\times E$. camaldulensis. The infestation level in E. tereticornis (446 lerps/individual) and E. camaldulensis (356 lerps/individual) is significantly higher in comparison to the other species $(P<0.05)$. The hybrids $E$. grandis $\times E$. tereticornis and E. grandis $\times E$. camaldulensis showed lower infestation rates, 25 and 21.4 lerps/individual, respectively, significantly different from the other species $(P<0.05)$. Finally, E. grandis and E. saligna showed the least infestation rates, 3 and 4.6 lerps/individual, respectively. Based on the lerps abundance per individual, the Eucalyptus species were classified into different categories: nonsusceptible (E. globulus ssp. maidenii, E. globulus ssp. globulus, E. sideroxylon, E. viminalis, E. cinerea, E. dunnii, and E. gunnii), slightly susceptible (E. grandis and E. saligna), moderately susceptible (E. grandis $\times$ E. tereticornis and $E$. grandis $\times E$. camaldulensis), and highly susceptible $(E$. camaldulensis and E. tereticornis).

E. dunnii, E. globulus ssp. maidenii, E. globulus ssp. globulus, E. viminalis, E. cinerea, E. sideroxylon, and E. gunnii were not infested by $G$. brimblecombei (0 lerps/individual).

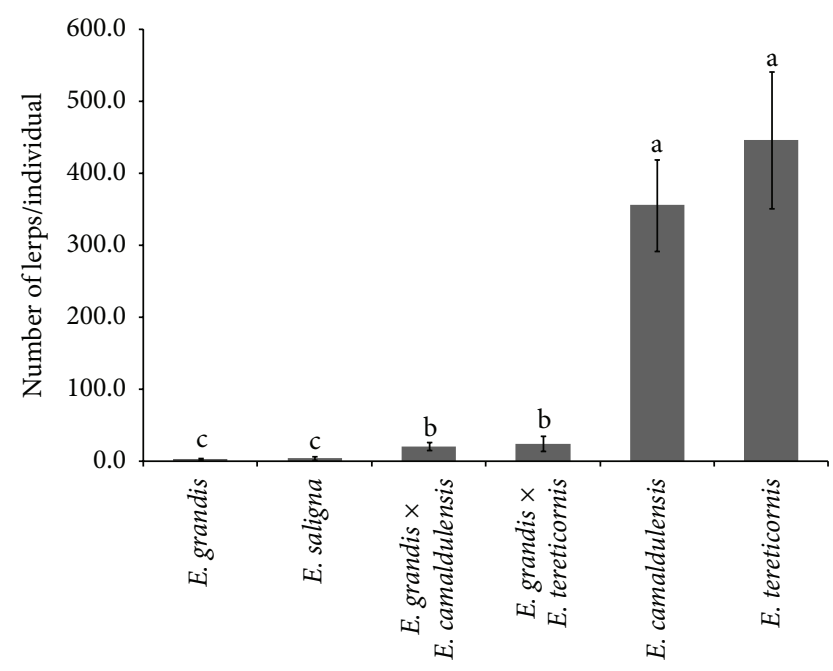

FIGURE 1: Lerps abundance of Glycaspis brimblecombei on infested Eucalyptus species. Each bar represents the mean of number of lerps per individual \pm SE. Bars with different letters are significantly different (Tukey's HSD mean multiple comparison test, $P<0.05$ ). Uninfested species (E. dunnii, E. globulus ssp. maidenii, E. globulus ssp. globulus, E. viminalis, E. cinerea, E. sideroxylon, and E. gunnii) are not showed.

TABLE 2: Essential oil yields, expressed as the mean of four replicates and standard deviation. Data from Lucia et al., 2008 [16].

\begin{tabular}{lc}
\hline Eucalyptus species & Yield (\% w/w) \pm standard deviation \\
\hline E. cinerea & $2.48 \pm 0.09$ \\
E. globulus ssp. maidenii & $2.25 \pm 0.05$ \\
E. globulus ssp. globulus & $1.66 \pm 0.05$ \\
E. sideroxylon & $1.65 \pm 0.06$ \\
E. viminalis & $1.46 \pm 0.05$ \\
E. grandis $\times$ E. tereticornis & $0.88 \pm 0.02$ \\
E. dunnii & $0.62 \pm 0.02$ \\
E. tereticornis & $0.59 \pm 0.03$ \\
E. grandis $\times$ E. camaldulensis & $0.54 \pm 0.04$ \\
E. camaldulensis & $0.38 \pm 0.01$ \\
E. saligna & $0.36 \pm 0.01$ \\
E. gunnii & $0.21 \pm 0.01$
\end{tabular}

Six from the uninfested species exhibited a high essential oil yield and a very high content of the terpene 1,8-cineole: E. globulus ssp. maidenii (77.91\%), E. globulus ssp. globulus (76.66\%), E. sideroxylon (91.27\%), E. viminalis (85.03\%), E. cinerea (79.84\%), and E. dunnii (48.48\%) (Tables 2 and 3, resp.).

The chemical composition and the respective yield obtained for each essential oil are showed (Tables 2 and 3). Qualitative differences in the infestation rate of G. brimblecombei were observed in relation to the chemical composition of Eucalyptus essential oils. The most infested species of Eucalyptus (E. tereticornis and E. camaldulensis) share several components, which are not found in other species: $\alpha$-thujene (1.99-1.70\%); sabinene (1.26-1.05\%); $\alpha$ terpinene $(<1 \%) ; \beta$-phellandrene (22.64-16.34\%); linalool 
TABLE 3: Chemical composition of essential oils from 13 species of Eucalyptus, expressed as a relative percentage of the total area of the chromatogram (TIC). a: main constituents of essential oils, determined with CG-MS; b: numbers represent the botanical names; 1 : E. grandis $\times$ E. tereticornis; 2: E. grandis $\times$ E. camaldulensis; 3: E. tereticornis; 4: E. camaldulensis; 5: E. saligna; 6: E. cinerea; 7: E. dunnii; 8: E. gunnii; 9: E. globulus ssp. maidenii; 10: E. globulus ssp. globulus; 11: E. sideroxylon; 12: E. viminalis; 13: E. grandis; c: data from Lucia et al., 2008 [16]; d: data from Lucia et al., 2007 [17].

\begin{tabular}{|c|c|c|c|c|c|c|c|c|c|c|c|c|c|}
\hline \multirow{2}{*}{ Oil constituents $^{\mathrm{a}}$} & \multicolumn{13}{|c|}{ Eucalyptus species ${ }^{\mathrm{b}}$} \\
\hline & $1^{\mathrm{c}}$ & $2^{c}$ & $3^{c}$ & $4^{c}$ & $5^{\mathrm{c}}$ & $6^{c}$ & $7^{\mathrm{c}}$ & $8^{\mathrm{c}}$ & $9^{c}$ & $10^{\mathrm{c}}$ & $11^{\mathrm{c}}$ & $12^{\mathrm{c}}$ & $13^{\mathrm{d}}$ \\
\hline$\alpha$-Thujene & - & - & 1.99 & 1.7 & - & - & - & $<1$ & - & - & - & - & - \\
\hline$\alpha$-Pinene & 22.8 & 30.65 & 1.35 & $<1$ & 12.95 & 4.94 & 5.45 & 4.06 & 5.84 & 11.09 & 1.95 & 1.16 & 52.71 \\
\hline Camphene & - & $<1$ & - & - & - & - & - & - & - & - & - & - & - \\
\hline$\beta$-Pinene & 3.29 & 1.1 & - & - & - & - & - & - & - & - & - & - & - \\
\hline Sabinene & - & - & 1.26 & 1.05 & - & - & - & - & - & - & - & - & - \\
\hline Myrcene & - & - & 1.54 & 1.21 & - & $<1$ & - & $<1$ & $<1$ & $<1$ & - & $<1$ & - \\
\hline$\alpha$-Phellandrene & - & - & 9.44 & 6.45 & - & - & 1.37 & 7.05 & - & - & - & $<1$ & - \\
\hline Linalool acetate & - & 1.43 & - & - & - & - & - & - & - & - & - & - & - \\
\hline$\alpha$-Terpinene & - & - & $<1$ & $<1$ & - & - & - & - & - & - & - & - & - \\
\hline p-Cymene & 1.92 & 2.77 & 14.51 & 17.93 & 21.25 & 1.63 & 4.43 & 12.28 & 2.31 & - & 1.77 & 1.93 & 9.7 \\
\hline$\beta$-Phellandrene & - & - & 22.64 & 16.34 & - & - & - & - & - & - & - & - & - \\
\hline 1,8-Cineole & 63.04 & 49.65 & 18.59 & 19.13 & 34.02 & 79.84 & 48.48 & 17.95 & 77.91 & 76.66 & 91.27 & 85.03 & 18.38 \\
\hline cis-Ocimene & - & - & - & - & - & - & $<1$ & 1.14 & - & - & - & - & - \\
\hline$\gamma$-Terpinene & - & - & 2.25 & 1.87 & 20.13 & - & 12.96 & 3.35 & 4.82 & $<1$ & - & - & 5 \\
\hline$\alpha$-Terpinolene & - & - & - & $<1$ & - & - & $<1$ & - & - & - & - & - & - \\
\hline Linalool & - & - & $<1$ & 3.08 & - & - & - & - & - & - & - & - & - \\
\hline$p$-Menthane-2-en-1-ol & - & - & $<1$ & $<1$ & - & - & - & - & - & - & - & - & - \\
\hline Fenchol & $<1$ & $<1$ & - & - & - & - & - & - & - & - & - & - & - \\
\hline Cryptone & - & - & 4.14 & 5.71 & - & - & - & - & - & - & - & - & - \\
\hline$\alpha$-Campholene aldehyde & $<1$ & $<1$ & - & - & 1.15 & - & - & - & - & - & - & - & 1.18 \\
\hline trans-Pinocarveol & 1.22 & 2.75 & - & - & $<1$ & - & - & - & - & - & - & - & 1.93 \\
\hline Borneol & 1 & 1.42 & - & - & $<1$ & - & - & - & - & - & - & - & 2.95 \\
\hline 4-Terpineol & $<1$ & $<1$ & 5.83 & 6.73 & 2.63 & $<1$ & 3.56 & 1.86 & 1.58 & $<1$ & $<1$ & $<1$ & 1.04 \\
\hline$\alpha$-Terpineol & 2.55 & 4.05 & 1.59 & - & 3.45 & 3.79 & 3.59 & 1.38 & 6.04 & 1.45 & 2.61 & 1.75 & 5.67 \\
\hline$\alpha$-Terpineol acetate & - & - & - & - & - & 8.2 & 5.14 & - & - & 3.98 & - & - & - \\
\hline trans-Caryophyllene & - & - & - & - & - & - & - & 2.12 & - & - & - & - & - \\
\hline Aromadendrene & - & - & - & - & - & - & 3.40 & 1.21 & - & 1.11 & - & 1.98 & - \\
\hline$\alpha$-Humulene & - & - & - & - & - & - & - & $<1$ & - & - & - & - & - \\
\hline Alloaromadendrene & - & - & - & - & - & - & $<1$ & 1.67 & - & - & - & - & - \\
\hline trans-Carveol & - & - & - & - & $<1$ & - & - & - & - & - & - & - & - \\
\hline Carvacrol & - & - & - & - & $<1$ & - & - & - & - & - & - & - & - \\
\hline 4-Isopropylbenzaldehyde & - & - & 1.32 & 2.6 & - & - & - & - & - & - & - & - & - \\
\hline Phellandral & - & - & $<1$ & 1.45 & - & - & - & - & - & - & - & - & - \\
\hline$\gamma$-Elemene & - & - & $<1$ & - & - & - & - & - & - & - & - & - & - \\
\hline Caryophyllene oxide & - & - & 1.69 & - & - & - & - & - & - & - & - & - & - \\
\hline Epiglobulol & - & - & - & - & - & - & $<1$ & $<1$ & - & - & - & 1.24 & - \\
\hline Spathulenol & $<1$ & $<1$ & 6.83 & 7.32 & - & - & - & 12.28 & - & - & - & - & - \\
\hline Globulol & $<1$ & - & - & - & - & - & 4.15 & $<1$ & - & - & - & 2.49 & - \\
\hline Unidentified compounds & 1.56 & 2.66 & 2.01 & 2.96 & 2.43 & 1.22 & 6.89 & 16.20 & 0.7 & 1.7 & 1.64 & 1.85 & 1.43 \\
\hline
\end{tabular}

(<1-3.08\%); p-menth-2-en-1-ol (<1\%); cryptone $(4.14-5.71 \%)$; 4 -isopropylbenzaldehyde (1.32-2.60\%); and phellandral $(<1-$ $1.45 \%)$.

The regression analysis between infestation rate and the relative concentration of several compounds of essential oils was based only on the six Eucalyptus species that were infested with G. brimblecombei. The simple regression analysis showed a statistically significant relationship between infestation rate and the following components: $\alpha$ phellandrene ( $F$ : 453; DG: $\left.5 ; P<0.01 ; R^{2}: 99\right)$, $\beta$-phellandrene ( $F$ : 829; DG: $5 ; P<0.01 ; R^{2}$ : 99). The multiple regression analyses showed a significant relationship between 
infestation rate and the relative concentration of 1,8-cineole $(P<0.01)$; due to the values of $F(3450.5)$ and $R^{2}(99.9)$ of the new model ( $\left.P_{\text {value model }}: 0.0003\right)$, it was decided to include it. The equation of the fitted model is as follows: number of lerps $=-9.39+0.55 * 1,8$-cineole $(\%)+58.19 *$ $\beta$-phellandrene (\%) - $92.39 * \alpha$-phellandrene (\%).

The statistics of each compound were as follows: $\alpha$ phellandrene (SE: 15.3; T: -6.02; $P<0.05$ ), $\beta$-phellandrene (SE: 6.31; T: 9.21; $P<0.05$ ), and 1,8-cineole (SE: 0.13; T: 4.17; $P<0.05)$. The $R$-squared $\left(R^{2}\right)$ statistic indicates that the model as fitted explains $99.9 \%$ of the variability in number of lerps. The adjusted $R$-squared statistic, which is more suitable for comparing models with different numbers of independent variables, is $99.9 \%$. The standard error of the estimate shows the standard deviation of the residuals to be 4.45. The mean absolute error (MAE) of 1.82 is the average value of the residuals. The Durbin-Watson (DW) statistic tests the residuals to determine if there is any significant correlation based on the order in which they occur in your data file. Since the DW value $(S=2.4)$ is greater than 1.4 , there is not any significant autocorrelation in the residuals. In determining whether the model can be simplified, notice that the highest $P$ value on the independent variables is 0.05 , belonging to 1,8 -cineole.

\section{Discussion}

According to these results, the composition of the essential oils in Eucalyptus should play an important role in theinfestation with $G$. brimblecombei. Both chemical and biological insecticides have been used in an attempt to control infestations of the red gum lerp psyllid. Contact insecticides are known to be ineffective as the immatures are protected by their shields (i.e., lerps) $[1,2]$. Systemic insecticides have been used with some success, but their use is of limited value in plantation forestry due to the high cost.

The performance of adult psyllids was previously studied by in no-choice experiments on juvenile and adult leaves of Eucalyptus globulus and it was concluded that the epicuticular wax of juvenile leaves plays an important role in resistance to G. brimblecombei; however it was suggested that other unknown factors are probably involved [18]. The blend composition of essential oils could be, probably, a cause of tolerance of Eucalyptus species to G. brimblecombei. The differences in the chemical composition could be responsible for the female oviposition choice, explaining the different infestation rates. E. gunnii, despite its low content of 1,8cineole, remained also uninfested. The chemical composition of the essential oil of E. gunnii is similar to E. tereticornis and E. camaldulensis, except for the lack of $\beta$-phellandrene in the first one. Besides, in comparison to the other species, E. gunnii has $16.20 \%$ of unidentified compounds. One of these might be involved in the plant-insect interaction, preventing the infestation by G. brimblecombei.

Different behavioral responses for an oviposition choice were observed in other insects that affect Eucalyptus. For example, Mnesampela privata Guénée females use terpenes as chemical clues for oviposition choice by the female [19].
It has been previously demonstrated that the most susceptible species are E. camaldulensis and E. nitens; meanwhile in E. grandis, E. globulus, and E. viminalis the susceptibility is between low and medium [20]. The species that are commercially reared in Brazil and highly susceptible to the infestation are E. camaldulensis and E. tereticornis, both known as "red Eucalyptus"; E. grandis and E. saligna are partially susceptible $[5,8]$.

The immatures of G. brimblecombei are covered by a wax layer called lerp. The immatures use this lerp as protection from climatic conditions. This adaptation could be responsible for the increment in the concentration of the essential oils under the lerp. When the insects are exposed to these vapors, the volatile substances enter through the spiracles and subsequently are transported to various tissues by the tracheas and tracheoles net arriving, finally, at their action site [21]. These kind of substances also circulate through the hemolymph free, in solution, or absorbed by proteins, and spreads throughout the body of the insect [22].

The fumigant toxicity of Eucalyptus essential oils against different insects was attributed to 1,8-cineole: Musca domestica Linnaeus [23], Pediculus humanus capitis De Geer [24], Haematobia irritans Linnaeus [25], Aedes aegypti Linnaeus [16], and Blattella germanica Linnaeus [26]. The correlation between fumigant toxicity and vapor pressures (i.e., volatility) of the components present in the essential oil was in accordance with previous studies [27]. The toxic effect of volatile substances penetrating through the insect spiracles, as part of the respiratory process, is strongly associated with their rate of volatility [28]. Consequently, Rice and Coats [29] evaluated the knockdown effect of 22 monoterpenes against $M$. domestica and found a polynomial correlation between their fumigant toxicity and their corresponding volatility, leading to the conclusion that the toxicity becomes greater when the monoterpene increases in volatility. The fast knockdown effect produced by 1,8-cineole in head lice, $P$. humanus capitis, suggests that this monoterpene probably has a neurotoxic effect. The toxic action of monoterpenoids may be mediated by pathways such as GABA receptors [30] and octopamine receptors [31, 32]. For such reason, the partition properties of these compounds play an important role in the penetration and distribution, until they reach the action site. Therefore, the low infestation with G. brimblecombei on some Eucalyptus species could be related to the fumigant toxicity of 1,8 -cineole present in the essential oils.

The interspecific hybrids of Eucalyptus have been used in forestry for decades [33]. The main areas planted with hybrids on a large scale are in Brazil, Congo, China, Indonesia, and South Africa. However, there are also small plantations in other countries in Asia (e.g., Philippines, Vietnam, Thailand, and Malaysia) and South America (e.g., Argentina, Chile, Paraguay, and Uruguay) [34]. Besides growth, the main traits which have been improved by hybridization include propagation, coppicing, frost, drought and salt resistance, wood density, resistance to pests, and pulp yield [35]. On the other hand, Eucalyptus hybridization has been used as a technique to improve the quality and quantity of essential oils [36]. 


\section{Conclusions}

The lerp abundance was significantly lower in those species of Eucalyptus with high essential oil yield and very high content of 1,8-cineole. The terpenes $\alpha$ - and $\beta$-phellandrene are the major components in the most infested Eucalyptus species. The low infestation of G. brimblecombei in those Eucalyptus species rich in 1,8-cineole could be attributed to the toxicity of this component for the immatures that live under the lerp. For the hybrid species, the results suggest that the low infestation rate with respect to the pure species could be due to the increment of 1,8-cineole in the essential oils. These findings are important because they give a clue about the susceptibility and tolerance to the attack of the psyllid in relation to the blend of terpenes in the essential oil. Yield, profile, and chemical composition of essential oils are genetically controlled by different enzymes related to terpene biosynthesis $[37,38]$. However, it is important to have knowledge about the heritability of terpene components to use controlled interspecific hybridization in order to obtain more resistant species.

\section{Conflict of Interests}

The authors declare that there is no conflict of interests regarding the publication of this paper.

\section{References}

[1] R. Garrison, New Agricultural Pest for Southern California Red Gum Lerp Psyllid, Glycaspis brimblecombei, Los Angeles County Agricultural Commissioner's Office, 1999.

[2] K. Daane, Biological Control of the Red Gum Lerp Psyllid, a Pest of Eucalyptus Species in California, University of California, 2004, http://cnr.berkeley.edu/biocon/dahlsten/rglp/index.htm.

[3] T. Olivares, A. Baldini, and L. Cerda, "El psílido de los eucaliptos rojos en Chile, Glycaspis brimblecombei Moore (Hemiptera, Psyllidae)," Corporación Nacional Forestal. Nota Técnica 45, Corporación Nacional Forestal, Santiago, Chile, 2003.

[4] K. M. Moore, "Observations on some Australian forest insects. A revision of the genus Glycaspis (Homoptera: Psyllidae) with descriptions of seventy-three new species," Australian Zoologist, vol. 15, pp. 248-342, 1970.

[5] M. Bianchi and A. Sánchez, "Glycaspis brimblecombei Moore (Homoptera: Psyllidae): un nuevo psílido asociado a Eucalyptus sp. Detectado recientemente en Brasil y Chile," in Forestal (Sociedad de Productores Forestales de Uruguay), vol. 24, pp. 810, 2004.

[6] J. P. R. Bouvet, L. Harrand, and D. Buckhardt, "Primera cita de Blastopsylla occidentalis y Glycaspis brimblecombei (Hemiptera: Psyllidae) para la República Argentina," Revista de la Sociedad Entomológica Argentina, vol. 64, no. 1-2, pp. 99-102, 2005.

[7] E. B. Brennan, R. J. Gill, G. F. Hrusa, and S. A. Weinbaum, "First record of Glycaspis brimblecombei Moore (Homoptera: Psyllidae) in North America: initial observations and predator associations of a potentially serious new pest of Eucalyptus in California," Pan-Pacific Entomologist, vol. 75, no. 1, pp. 55-57, 1999.

[8] D. C. Firmino, "Biología do psilídeo de concha Glycaspis briblecombei Moore (Hemiptera: Psyllidae) em diferentes espécies de eucalipto e em Eucalyptus camaldulensis sob diferentes temperaturas," in Tesis de Mestre em Agronomia (Proteção de Plantas), p. 51, Faculdade de Ciências Agronômicas da UNESP, Botucatu, Brazil, 2004.

[9] J. J. W. Coppen, "Eucalyptus oils. Flavours and fragrances of plant origin," in Non-Wood Forest Products, pp. 37-52, FAO, Rome, Italy, 1995.

[10] M. Marco and L. Harrand, "El mejoramiento genético forestal y su aporte al desarrollo del sector forestal regional," in Información Forestal. EEA, INTA Concordia, vol. 14, pp. 55-61, 1999.

[11] E. J. Macías-Sámano, Mediación Semioquímica Entre Insectos Descortezadores y Árboles de Coníferas. Relaciones Químicas Entre Organismos: Aspectos Básicos y Perspectivas de su Aplicación, Instituto de Ecología, UNAM, 2001.

[12] K. F. Raffa, B. H. Aukema, N. Erbilgin, K. D. Klepzig, and K. F. Wallin, "Interactions among conifer terpenoids and bark beetles across multiple levels of scale: an attempt to understand links between population patterns and physiological processes," in Chemical Ecology and Phytochemistry of Forest Ecosystems, vol. 39 of Recent Advances in Phytochemistry, pp. 79-118, Elsevier, 2005.

[13] L. R. Metcalf and E. R. Metcalf, Plant Kairomones in Insect Ecology and Control, vol. 1 of Contemporary Topics in Entomology, Springer, New York, NY, USA, 1992.

[14] J. M. Pereira, E. L. L. Baldin, E. P. Soliman, and C. F. Wilcken, "Attractiveness and oviposition preference of Glycaspis brimblecombei Moore in Eucalyptus spp.", Phytoparasitica, vol. 41, no. 2, pp. 117-124, 2013.

[15] T. H. Jones, B. M. Potts, R. E. Vaillancourt, and N. W. Davies, "Genetic resistance of Eucalyptus globulus to autumn gum moth defoliation and the role of cuticular waxes," Canadian Journal of Forest Research, vol. 32, no. 11, pp. 1961-1969, 2002.

[16] A. Lucia, S. Licastro, E. Zerba, and H. M. Masuh, "Yield, chemical composition, and bioactivity of essential oils from 12 species of Eucalyptus on Aedes aegypti larvae," Entomologia Experimentalis et Applicata, vol. 129, no. 1, pp. 107-114, 2008.

[17] A. Lucia, P. G. Audino, E. Seccacini, S. Licastro, E. Zerba, and H. Masuh, "Larvicidal effect of Eucalyptus grandis essential oil and turpentine and their major components on Aedes Aegypti larvae," Journal of the American Mosquito Control Association, vol. 23, no. 3, pp. 299-303, 2007.

[18] E. B. Brennan, G. F. Hrusa, S. A. Weinbaum, and W. Levison Jr., "Resistance of Eucalyptus species to Glycaspis brimblecombei (Homoptera: Psyllidae) in the San Francisco bay area," PanPacific Entomologist, vol. 77, no. 4, pp. 249-253, 2001.

[19] M. J. Steinbauer, F. P. Schiestl, and N. W. Davies, "Monoterpenes and epicuticular waxes help female autumn gum moth differentiate between waxy and glossy Eucalyptus and leaves of different ages," Journal of Chemical Ecology, vol. 30, no. 6, pp. 1117-1142, 2004.

[20] S. Ide, C. Muñoz, M. Beéche et al., "Detección y control biológico de Glycaspis brimblecombei MOORE (Hemiptera: Psyllidae), servicio agrícola y ganadero, división protección agrícola," in Subdepartamento Vigilancia y Control de Plagas Forestales y Exóticas Invasora, pp. 1-32, Subdepartamento Vigilancia y Control de Plagas Forestales y Exóticas Invasora, Santiago, Chile, 2006.

[21] P. J. Mill, "Structure and physiology of the respiratory system," in Comprehensive Insect Physiology, Biochemistry and Pharmacology, Insect, vol. 3, pp. 517-593, Pergamon Press, Oxford, UK, 1985. 
[22] W. Welling and G. D. Paterson, "Toxicodynamics of insecticides," in Comprehensive Insect Physiology Biochemistry and Pharmacology, Insect Control, vol. 12, pp. 603-646, Pergamon Press, Oxford, UK, 1985.

[23] G. Tarelli, E. N. Zerba, and R. A. Alzogaray, "Toxicity to vapor exposure and topical application of essential oils and monoterpenes on Musca domestica (Diptera: Muscidae)," Journal of Economic Entomology, vol. 102, no. 3, pp. 1383-1388, 2009.

[24] A. C. Toloza, A. Lucia, E. Zerba, H. Masuh, and M. I. Picollo, "Interspecific hybridization of Eucalyptus as a potential tool to improve the bioactivity of essential oils against permethrinresistant head lice from Argentina," Bioresource Technology, vol. 99, no. 15, pp. 7341-7347, 2008.

[25] L. W. Juan, A. Lucia, E. N. Zerba, L. Harrand, M. Marco, and H. M. Masuh, "Chemical composition and fumigant toxicity of the essential oils from 16 species of Eucalyptus against Haematobia irritans (Diptera: Muscidae) adults," Journal of Economic Entomology, vol. 104, no. 3, pp. 1087-1092, 2011.

[26] R. A. Alzogaray, A. Lucia, E. N. Zerba, and H. M. Masuh, "Insecticidal activity of essential oils from eleven Eucalyptus spp. and two hybrids: lethal and sublethal effects of their major components on Blattella germanica," Journal of Economic Entomology, vol. 104, no. 2, pp. 595-600, 2011.

[27] C. Hansch, Quantitative Structure-Activity Relationship, vol. 1 of Drug Design, Academic Press, New York, NY, USA, 1971.

[28] A. Lucia, E. Zerba, and H. M. Masuh, "Knockdown and larvicidal activity of six monoterpenes against Aedes aegypti (Diptera: Culicidae) and their structure-activity relationships," Parasitology Research, vol. 112, no. 12, pp. 4267-4272, 2013.

[29] P. J. Rice and J. R. Coats, "Insecticidal properties of several monoterpenoids to the house fly (Diptera: Muscidae), red flour beetle (Coleoptera: Tenebrionidae), and southern corn rootworm (Coleoptera: Chrysomelidae)," Journal of Economic Entomology, vol. 87, no. 5, pp. 1172-1179, 1994.

[30] C. M. Priestley, E. M. Williamson, K. A. Wafford, and D. B. Sattelle, "Thymol, a constituent of thyme essential oil, is a positive allosteric modulator of human $\mathrm{GABA}_{\mathrm{A}}$ receptors and a homooligomeric GABA receptor from Drosophila melanogaster," British Journal of Pharmacology, vol. 140, no. 8, pp. 1363-1372, 2003.

[31] E. Enan, "Insecticidal activity of essential oils: octopaminergic sites of action," Comparative Biochemistry and Physiology C: Toxicology and Pharmacology, vol. 130, no. 3, pp. 325-337, 2001.

[32] M. Kostyukovsky, A. Rafaeli, C. Gileadi, N. Demchenko, and E. Shaaya, "Activation of octopaminergic receptors by essential oil constituents isolated from aromatic plants: possible mode of action against insect pests," Pest Management Science, vol. 58, no. 11, pp. 1101-1106, 2002.

[33] A. R. Griffin, I. Burgess, and L. Wolf, "Patterns of natural and manipulated hybridisation in the genus Eucalyptus L'Herit. A review," Australian Journal of Botany, vol. 36, no. 1, pp. 41-66, 1988.

[34] H. S. Dungey and D. G. Nikles, "An international survey of interspecific hybrids in forestry," in Hybrid Breeding and Genetics of Forest Trees. Proceedings of the QFRI/CRC-SPF Symposium, pp. 419-425, Department of Primary Industries, Brisbane, Australia, 2000.

[35] B. M. Potts and H. S. Dungey, "Interspecific hybridization of Eucalyptus: key issues for breeders and geneticists," New Forests, vol. 27, no. 1, pp. 115-138, 2004.

[36] A. Farah, M. Fechtal, and A. Chaouch, "Effet de l'hybridation interspécifique sur la teneur et la composition chimique des huiles essentielles d'Eucalyptus cultivés au Maroc," Biotechnology Agronomy Society and Environment, vol. 6, no. 3, pp. 163169,2002

[37] A. Keszei, C. L. Brubaker, and W. J. Foley, "A molecular perspective on terpene variation in Australian Myrtaceae," Australian Journal of Botany, vol. 56, no. 3, pp. 197-213, 2008.

[38] M. Shepherd, J. X. Chaparro, and R. Teasdale, "Genetic mapping of monoterpene composition in an interspecific eucalypt hybrid," Theoretical and Applied Genetics, vol. 99, no. 7-8, pp. 1207-1215, 1999. 

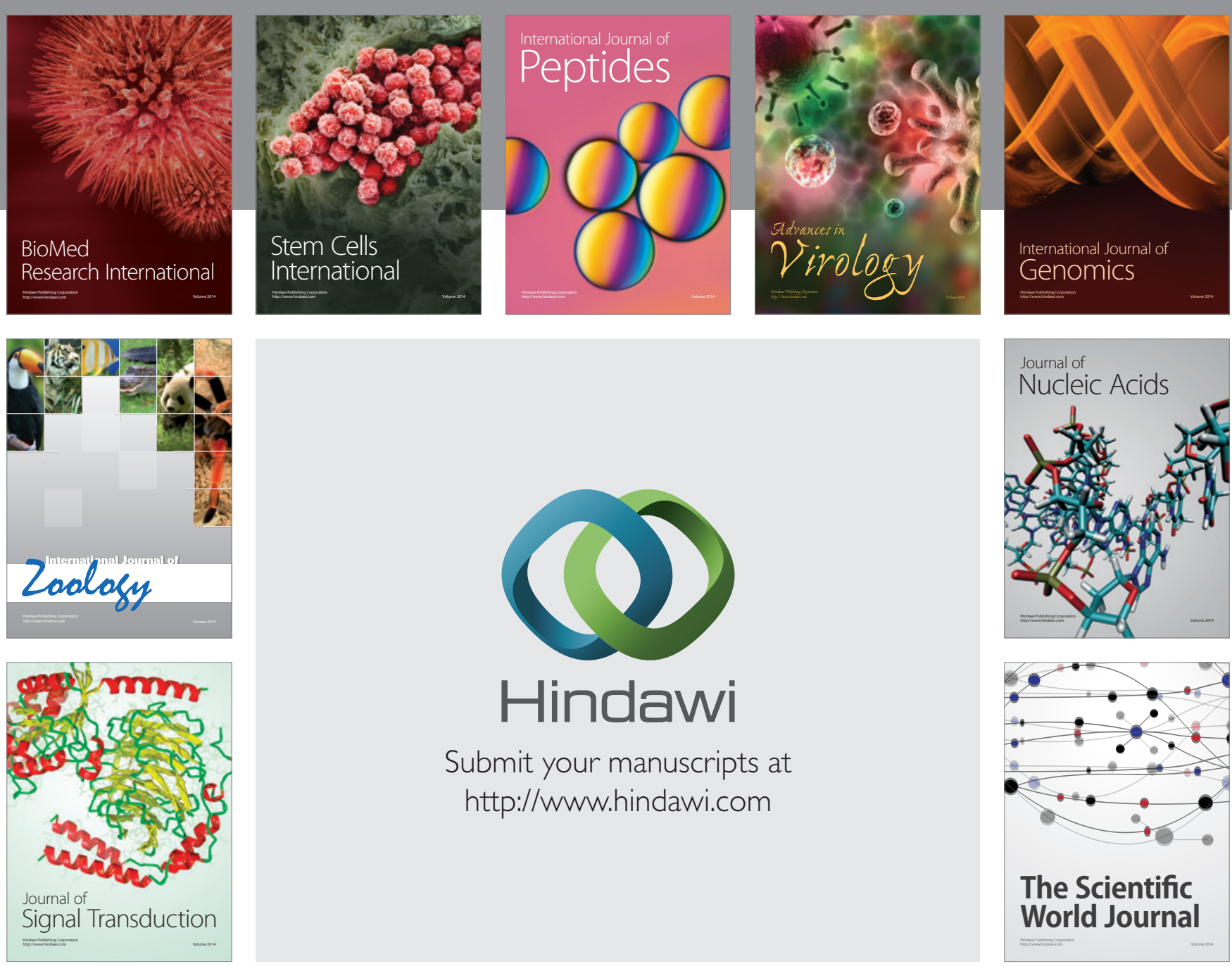

Submit your manuscripts at

http://www.hindawi.com
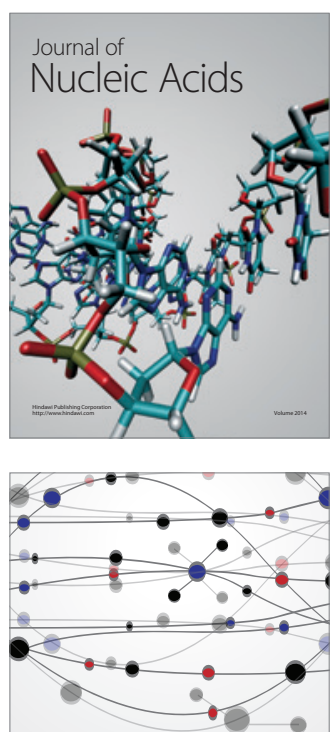

The Scientific World Journal
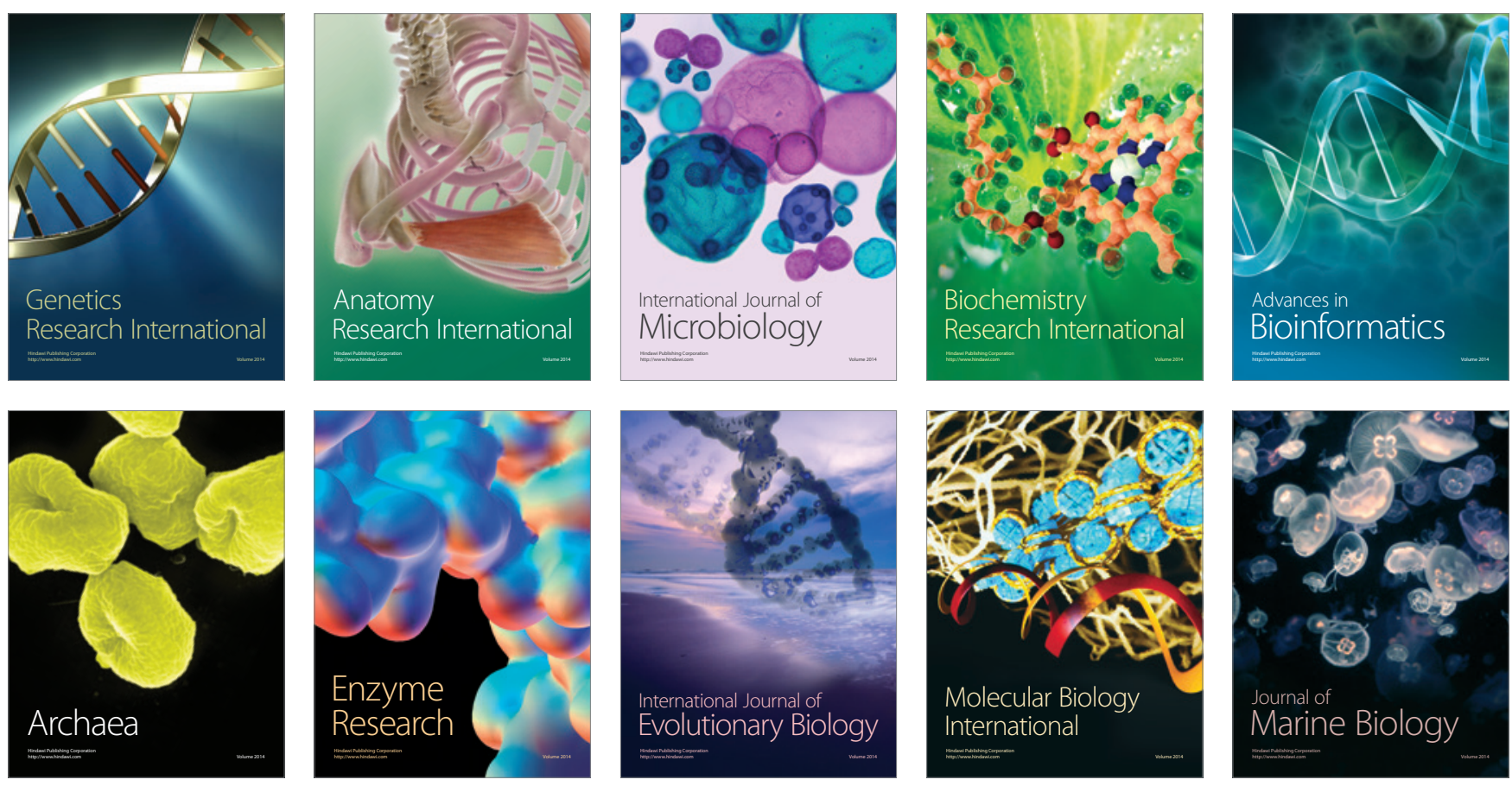